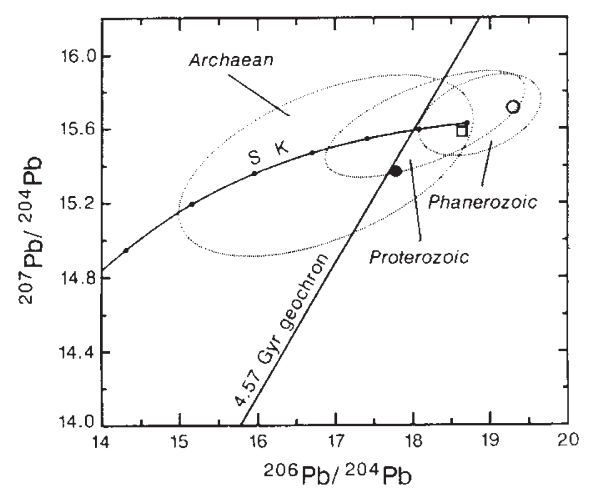

The $\mathrm{Pb}$ isotopic fields of young (less than 200 million years old) felsic plutonic and volcanic rocks derived from lower continental crust of Archaean $(n=122, \alpha=17.12, \beta=15.32)$, Proterozoic $(n=243, \alpha=17.89, \beta=15.52)$ and Phanerozoic $(n=347, \alpha=18.76, \beta=15.65)$ age $-n$, number of samples; $\alpha$, averaage ${ }^{206} \mathrm{~Pb} /{ }^{204} \mathrm{~Pb}$; and $\beta$, average ${ }^{207} \mathrm{~Pb} /{ }^{204} \mathrm{~Pb}$. Also shown is the $\mathrm{Pb}$ isotopic composition of the lower crust (solid circle), upper crust (open circle), and total crust (square) as modelled by Zartman and Haines ${ }^{5}$. The preferred values of Rudnick and Goldstein ${ }^{1}$ for the corresponding reservoirs lie slightly to the left of these points. The 4.57 thousand million year (Gyr) geochron and Stacey and Kramers ${ }^{6}$ growth curve (labelled S-K, ticks at 0.4-Gyr intervals) are shown for reference.

the Earth as a whole.

Another line of evidence relating to the $\mathrm{Pb}$ isotopic character of the lower crust seems increasingly relevant, and also suggests a total crust displaced well to the right of the geochron in $\mathrm{Pb}$ isotope space. Because of the rarity of actual samples of the lower crust - chiefly limited to kimberlite- and basalt-hosted xenoliths and a few tectonically uplifted terranes - considerable interest has focused on the $\mathrm{Pb}$ isotope ratios of young felsic plutonic and volcanic rocks derived from lower crustal sources of various ages and tectonic settings (see figure). This worldwide data set, which includes hundreds of analyses, should minimize sampling bias, and, consequently, can be used to calculate an average $\mathrm{Pb}$ isotopic composition for large volumes of the lower crust. Despite some uncertainty in age and $\mathrm{Pb}$ concentration of the source rock, the evidence so obtained for a time-integrated $\mu$-value in the lower crust of $6-8$, rather than about 1 or less, is overwhelming, that is the lower crust itself lies close to the geochron. Although continuing to support a somewhat diminished isotopic evolution compared to the upper crust, the highly unradiogenic reservoir required to solve the $\mathrm{Pb}$ paradox has not been identified in the young igneous rocks. Still, very-low- $\mu$ felsic granulites do occur fairly commonly as xenoliths and in some deeply exposed terranes, and they cannot be ignored as a component of continental crust.

The answer to this apparent contradiction in the composition of the crust may lie with the mafic granulites themselves.

\title{
Plants in the post
}

EARLIER this month the United Nations Postal Administration issued a set of six stamps commemorating the work of its sister body UNIDO with medicinal plants. Over the past five years, UNIDO (United Nations Industrial Development Organization) has been involved in promoting the industrial production of medicine from wild plants in developing countries as a low-cost, readily available alternative to the more

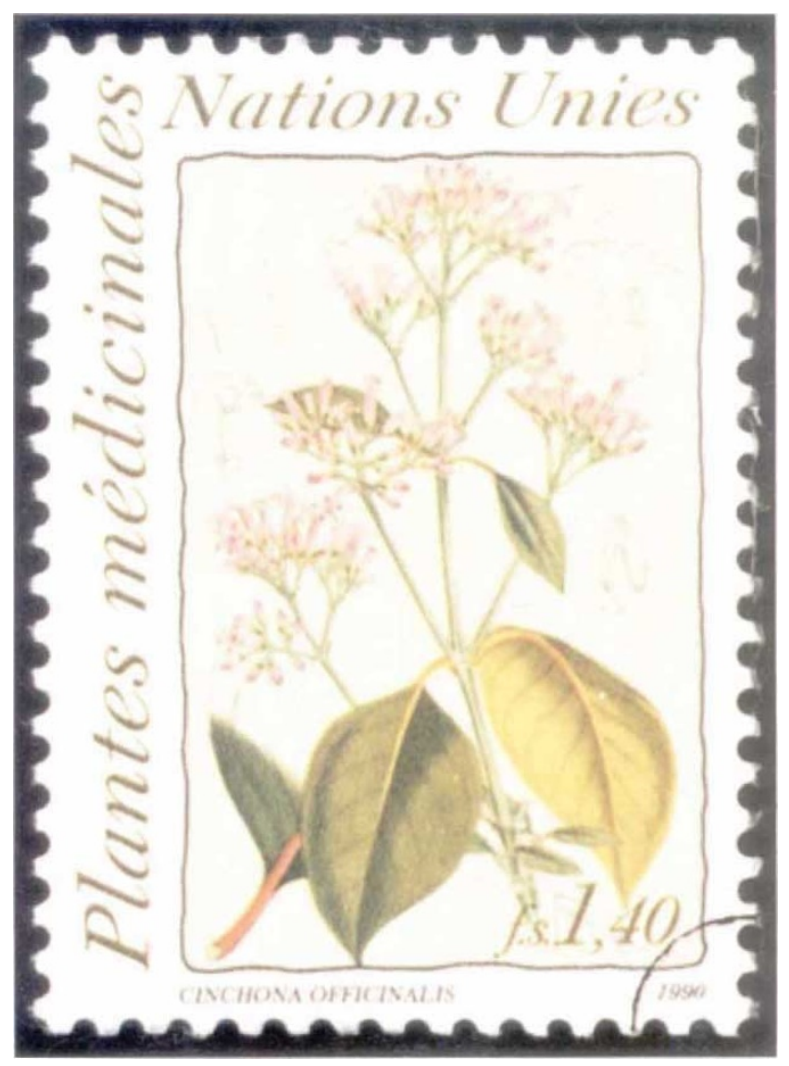
expensive conventional medicines marketed in developed countries.

The stamps, illustrated by watercolours from Botanic Magazine established by the eighteenthcentury botanist William Curtis, each show a plant noted for the beneficial effect of its products on health. Depicted here is Cinchona officinalis, an evergreen tree, native to the Andes of Ecuador and Peru. It is widely cultivated for the dried bark of its stems and roots, known as cinchona or Peruvian bark, the source of quinine and other antimalarial alkaloids. The tree was named after the Countess of Chinchon, wife of the Viceroy of Peru, who is said to have been cured of tertian fever in 1638 by a preparation of the bark.

Quinine has been largely replaced by synthetic anti-malarial drugs developed in response to the flow of quinine from Java being cut off by the Japanese during the Second World War; resistance to these drugs is now a large problem (see pages 202, 253 and 255).

The UN Postal Administration is the only body in the world without sovereign territory that has the right to issue its own stamps. The new issue is available in three currencies, but can be used for postage only from certain UN headquarters unfortunately, not most people's usual stamping ground.

Peter Tallack

Bohlen and Mezger ${ }^{\top}$ have summarized the argument for a three-tiered crust in which, in addition to the unmetamorphosed to moderately metamorphosed upper crust, high-grade felsic granulites comprise the middle crust, and underplated mafic granulites comprise the lower crust. If the mafic granulites do represent a later addition to the crust and acquire their isotopic signatures from invaded older rock without an abnormally low $\mu$ value, a reconciliation between the measurements of mafic granulites and the indirect evidence provided by young igneous rocks becomes possible. Preserved enclaves of ancient, low- $\mu$ felsic granulites may be less abundant than once thought, and may also be mainly restricted to intermediate crustal levels.

As Rudnick and Goldstein point out, any attempt to extrapolate their limited data to an average crustal $\mathrm{Pb}$ isotopic composition leaves many questions unanswered about the structure, compo- sition and age of a crust, which, apparently, grows both laterally and vertically. A significant 'younging' of the continental crust with depth will require a re-evaluation of most models that assume that the age of the crust does not change with depth. In the process of redefining the nature of the deeper continental crust, we appear to find ourselves back with the $\mathrm{Pb}$ paradox and with renewed speculation on its cause.

Robert Zartman is in the US Geological Survey, Branch of Isotope Geology, Denver, Colorado 80225, USA.

1. Rudnick, R.L. \& Goldstein, S.L. Earth planet. Sci. Lett. 98, 192-207 (1990)

2. Zartman, R.E. \& Wasserburg, G.J. Geochim. cosmochim Acta 33, 901-942 (1969).

3. Allègre, C. L. Earth planet. Sci. Lett. 5, 261-269 (1969).

4. Zartman, R.E. Eos65, 230 (1984).

5. Zartman, R.E. \& Haines, S.M. Geochim. cosmochim. Acta 52, 1327-1339 (1988)

6. Stacey, J.S. \& Kramers, J.D. Earth planet. Sci. Lett. 26. 207-221 (1975).

7. Bohlen, S.R. \& Mezger, K. Science 244, 326-329 (1989). 